\title{
Oleibacter marinus gen. nov., sp. nov., a bacterium that degrades petroleum aliphatic hydrocarbons in a tropical marine environment
}

\author{
Correspondence \\ Yukiyo Fukunaga \\ fukunaga-yukiyo@nite.go.jp
}

\author{
Maki Teramoto, ${ }^{1}+$ Motoyuki Ohuchi, ${ }^{1}$ Ariani Hatmanti, ${ }^{2}$ Yeti Darmayati, ${ }^{2}$ \\ Yantyati Widyastuti, ${ }^{3}$ Shigeaki Harayama ${ }^{1}$ and Yukiyo Fukunaga ${ }^{1} \dagger$
${ }^{1}$ NITE Biotechnology Development Center (NBDC), National Institute of Technology and Evaluation (NITE), 2-5-8 Kazusakamatari, Kisarazu, Chiba 292-0818, Japan
${ }^{2}$ Research Center for Oceanography, Indonesian Institute of Sciences (LIPI), Jakarta Utara 14430, Indonesia
${ }^{3}$ Research Center for Biotechnology, LIPI, Cibinong 16911, Indonesia

A wide variety of micro-organisms are known to degrade petroleum hydrocarbons (Head et al., 2006; Prince, 2005). Among the hydrocarbonoclastic bacteria, members of the genera Alcanivorax (Hara et al., 2003; Kasai et al., 2001; Roling et al., 2004; Yakimov et al., 1998, 2005) and Cycloclasticus (Dyksterhouse et al., 1995; Kasai et al., 2002; Maruyama et al., 2003) have been identified as key microorganisms in the degradation of aliphatic and aromatic hydrocarbons, respectively, in marine environments (Harayama et al., 2004). The genus Alcanivorax predominates in crude oil-impacted temperate marine environments (Cappello et al., 2007; Hara et al., 2003; Kasai et al., 2001; Roling et al., 2002, 2004; Yakimov et al., 2005).

†These authors contributed equally to this work.

The GenBank/EMBL/DDBJ accession numbers for the 16S rRNA gene sequences of strains $201^{\top}, 1014$ and 1018 are AB435649AB435651, respectively.

A supplementary table and three supplementary figures are available with the online version of this paper.
Members of the genus Thalassolituus have recently been shown to dominate in $\mathrm{n}$-alkane-containing temperate seawater microcosms (McKew et al., 2007; Yakimov et al., 2005) and in crude-oil-containing temperate estuarine seawater microcosms (Coulon et al., 2007; McKew et al., 2007). Strains related to the genus Oceanobacter dominate in crude-oil-impacted Indonesian seawater microcosms and show high n-alkane-degrading activity, which is comparable to that of the genus Alcanivorax and suggests that Oceanobacter-related bacteria could be important for the degradation of petroleum aliphatic hydrocarbons in tropical marine environments (Teramoto et al., 2009).

Three strains related to the genus Oceanobacter, designated $2 \mathrm{O}^{\mathrm{T}}, 1 \mathrm{O} 14$ and 1O18, were isolated from seawater collected at Pari Island $\left(5.86^{\circ} \mathrm{S} 106.62^{\circ} \mathrm{E}\right)$ located near Jakarta, Indonesia, after enrichment with crude oil and a continuous supply of the seawater supplemented with nitrogen, phosphorus and iron nutrients (Teramoto et al., 2009). The isolates exhibited distinct repetitive extragenic palindromic PCR patterns (Teramoto et al., 2009) and 
highest 16S rRNA gene sequence similarity with Oceanobacter kriegii IFO $15467^{\mathrm{T}}(96.4-96.5 \%)$. However, Oceanobacter kriegii NBRC $15467^{\mathrm{T}}$ did not show any petroleum hydrocarbon-degrading activity (Teramoto et al., 2009) and had a different spectrum of growth substrates from the isolates (Bowditch et al., 1984; Teramoto et al., 2009). The strains were deposited in the NBRC and the BTCC (Biotechnology Culture Collection, LIPI, Cibinong, Indonesia).

Strains $2 \mathrm{O} 1^{\mathrm{T}}$, $1 \mathrm{O} 14$ and $1 \mathrm{O} 18$ were cultivated on dMBPyr agar [containing $\left(1^{-1}\right) 3.74 \mathrm{~g}$ marine broth 2216 (Difco), $5 \mathrm{~g}$ sodium pyruvate, $1.5 \%(\mathrm{w} / \mathrm{v})$ agar, 0.11 distilled water and 0.91 seawater; marine broth 2216 was dissolved in distilled water by boiling for $1 \mathrm{~min}$ and filtered through a $0.45 \mu \mathrm{m}$ membrane (JHWPO 4700; Nihon Millipore) to remove insoluble components]. Phase-contrast microscopy showed that cells of the isolates were motile. Transmission electron microscopy (H7600; Hitachi) with freshly grown cells $\left(25^{\circ} \mathrm{C}\right)$ negatively stained with phosphotungstic acid showed rod-shaped $(0.3-0.6 \times 1.5-2.8 \mu \mathrm{m})$ and monoflagellated cells (Supplementary Fig. S1, available in IJSEM Online). Gram-staining tests with $3 \%(w / v) \mathrm{KOH}$ (Buck, 1982) and the staining procedure described by Gerhardt et al. (1994) showed that the isolates were Gram-negative. Tests for anaerobic growth were conducted on dMBPyr agar at $25{ }^{\circ} \mathrm{C}$ in a GasPak anaerobic jar (Becton Dickinson) for 3 weeks. The isolates did not grow under anaerobic conditions.

Growth of strains $2 \mathrm{O} 1^{\mathrm{T}}, 1 \mathrm{O} 14$ and $1 \mathrm{O} 18$ was tested on dMBPyr agar at $4,10,15,20,25,30,35,37$ and $40{ }^{\circ} \mathrm{C}$ for 25 days. Growth with $0,1,3,5,7,10,12,15,17$ and $20 \%$ (w/v) $\mathrm{NaCl}$ was tested on R2A agar (Difco) at $25{ }^{\circ} \mathrm{C}$ for 2 weeks. Growth at pH 2-11 (at intervals of $1 \mathrm{pH}$ unit) was tested in filter-sterilized dMBPyr broth inoculated with a small amount of freshly grown cells transferred from dMBPyr agar using a toothpick and incubated with shaking (125 r.p.m.) at $25{ }^{\circ} \mathrm{C}$ for 7 weeks. The isolates grew at $10-$ $40{ }^{\circ} \mathrm{C}$ (optimum $25-30{ }^{\circ} \mathrm{C}$ ), but not at $4{ }^{\circ} \mathrm{C}$, with $1-7 \%$ (w/v) $\mathrm{NaCl}$ and at $\mathrm{pH}$ 6-10 (optimum $\mathrm{pH}$ 6-9 for strains $2 \mathrm{O} 1^{\mathrm{T}}$ and $1 \mathrm{O} 14$ and $\mathrm{pH}$ 7-9 for strain 1O18).

Conditions for growth of Oceanobacter kriegii NBRC $15467^{\mathrm{T}}$ were also tested. Oceanobacter kriegii NBRC $15467^{\mathrm{T}}$ grew at $10-40{ }^{\circ} \mathrm{C}$ (optimum $25-30{ }^{\circ} \mathrm{C}$ ); previously, this strain was reported to be unable to grow at $40{ }^{\circ} \mathrm{C}$ (Bowditch et al., 1984). The $\mathrm{NaCl}$ concentration range and optimum for Oceanobacter kriegii NBRC $15467^{\mathrm{T}}$ were the same as those of the isolates, which was consistent with the report that this strain requires $>100 \mathrm{mM}(>0.58 \%$, w/v $)$ $\mathrm{NaCl}$ for optimal growth (Bowditch et al., 1984). The $\mathrm{pH}$ range for growth of Oceanobacter kriegii NBRC $15467^{\mathrm{T}}$ was tested for 3 days and was $\mathrm{pH}$ 5-9.

Catalase and oxidase activities of the isolates were assayed by dropping $3 \%(\mathrm{v} / \mathrm{v})$ hydrogen peroxide onto fresh cells on a glass slide and using oxidase reagent (bioMérieux), respectively. For physiological tests using the API 20 E, API $20 \mathrm{NE}$ and API ZYM systems (bioMérieux), cells freshly grown on dMBPyr agar at $25{ }^{\circ} \mathrm{C}$ were suspended in artificial seawater [38.39 $\mathrm{g}$ artificial sea salt $\mathrm{l}^{-1}$ (Marine Art SF-1; Tomita Pharmaceutical)] and the cell density was adjusted to an $\mathrm{OD}_{550}$ of 0.125 for API $20 \mathrm{E}$ and API $20 \mathrm{NE}$ and an $\mathrm{OD}_{550}$ of 1.5 for API ZYM. The plates were incubated at $30{ }^{\circ} \mathrm{C}$ and results were recorded after 2 days for API $20 \mathrm{E}$ and API $20 \mathrm{NE}$ and $4.5 \mathrm{~h}$ for API ZYM. Each isolate was tested in duplicate. The physiological properties of the isolates were identical. Strains $2 \mathrm{O} 1^{\mathrm{T}}, 1 \mathrm{O} 14$ and $1 \mathrm{O} 18$ were catalase- and oxidase-positive. With API $20 \mathrm{NE}$, the isolates were positive for urease, gelatinase and reduction of nitrate to nitrite and negative for indole production from tryptophan, fermentation of glucose, arginine dihydrolase, aesculin hydrolase, $\beta$-galactosidase and assimilation of L-arabinose, glucose, D-mannose, maltose, Dmannitol, $N$-acetyl-D-glucosamine, potassium gluconate, adipate, $\mathrm{n}$-caprate, DL-malate, sodium citrate and phenylacetate. With API $20 \mathrm{E}$, the isolates were negative for all tests: urease, gelatinase, $\beta$-galactosidase, arginine dihydrolase, lysine and ornithine decarboxylases, tryptophan deaminase, citrate utilization, $\mathrm{H}_{2} \mathrm{~S}$ production, indole production from tryptophan, acetoin production and fermentation/oxidation of arabinose, glucose, melibiose, rhamnose, sucrose, inositol, mannitol, sorbitol and amygdalin. The reason for the differences in results for urease and gelatinase from API $20 \mathrm{NE}$ and API $20 \mathrm{E}$ is unknown. The results with API ZYM are given in the species description.

Oceanobacter kriegii NBRC $15467^{\mathrm{T}}$ was also analysed with the API ZYM, API $20 \mathrm{NE}$ and API $20 \mathrm{E}$ systems. The following results were different from those of the novel isolates: with API ZYM, negative for lipase (C14) and cystine arylamidase; with API $20 \mathrm{NE}$, negative for urease; and with API $20 \mathrm{E}$, positive for arginine dihydrolase, citrate utilization, gelatinase and fermentation/oxidation of glucose. Oceanobacter kriegii NBRC $15467^{\mathrm{T}}$ was positive for gelatinase and reduction of nitrate to nitrite with API 20 $\mathrm{NE}$ and API $20 \mathrm{E}$, which differs from the negative result reported by Bowditch et al. (1984).

The analysis of fatty acid methyl esters used the Microbial Identification System (MIDI) with cells freshly grown on dMBPyr agar at $25^{\circ} \mathrm{C}$ for 20 days (strains $2 \mathrm{O} 1^{\mathrm{T}}, 1 \mathrm{O} 14$ and 1O18) or 3 days (Oceanobacter kriegii NBRC $15467^{\mathrm{T}}$ ). Fatty acids not identified by the system were further analysed using GC-MS (Agilent). The cellular fatty acid profiles are shown in Table 1 with that of the next closest phylogenetic neighbour with a validly published name, Thalassolituus oleivorans MIL- $1^{\mathrm{T}}$ (Yakimov et al. 2004). The predominant fatty acids of the isolates were $\mathrm{C}_{16: 0}, \mathrm{C}_{16: 1} \omega 7$ and $\mathrm{C}_{18: 1} \omega 9$ and the hydroxy fatty acids were $\mathrm{C}_{12: 0} 3-\mathrm{OH}$ and $\mathrm{C}_{10: 0} 3-$ OH. Oceanobacter kriegii NBRC $15467^{\mathrm{T}}$ contained $\mathrm{C}_{18: 1} \omega 7$ as a major fatty acid and did not contain $\mathrm{C}_{18: 1} \omega 9$. T. oleivorans MIL- ${ }^{\mathrm{T}}$ and the novel isolates did not contain $\mathrm{C}_{18: 1} \omega 7$ as a major fatty acid.

Isoprenoid quinones were extracted from cells grown in dMBPyr broth with shaking (125 r.p.m.) at $25^{\circ} \mathrm{C}$ to early 
Table 1. Cellular fatty acid compositions of strains $2 \mathrm{O} 1^{\top}$, 1014 and 1018 and their closest culturable phylogenetic neighbours

Strains: 1-3, Oleibacter marinus gen. nov., sp. nov. strains $2 \mathrm{O}^{\mathrm{T}}(1)$, $1 \mathrm{O} 14$ (2) and $1 \mathrm{O} 18$ (3); 4, Oceanobacter kriegii NBRC $15467^{\mathrm{T}} ; 5$, Thalassolituus oleivorans MIL- ${ }^{\mathrm{T}}$ (data from Yakimov et al., 2004). Values are percentages of total fatty acids. -, Not detected; ND, no data available.

\begin{tabular}{|lccccc|}
\hline Fatty acid & $\mathbf{1}$ & $\mathbf{2}$ & $\mathbf{3}$ & $\mathbf{4}$ & $\mathbf{5}$ \\
\hline $\mathrm{C}_{10: 0}$ & 2.6 & 4.6 & 3.1 & 0.2 & $\mathrm{ND}$ \\
$\mathrm{C}_{10: 0} 3-\mathrm{OH}$ & 1.8 & 2.5 & 1.7 & 2.0 & $\mathrm{ND}$ \\
$\mathrm{C}_{11: 0}$ & 0.3 & 0.5 & - & - & $\mathrm{ND}$ \\
$\mathrm{C}_{12: 0}$ & 7.7 & 8.3 & 7.9 & 7.7 & 2.0 \\
$\mathrm{C}_{12: 0} 3-\mathrm{OH}$ & 2.8 & 3.4 & 3.4 & 1.9 & 1.4 \\
$\mathrm{C}_{13: 1}$ & - & - & - & 0.2 & $\mathrm{ND}$ \\
$\mathrm{C}_{14: 1} \omega 9$ & - & - & - & - & 1.2 \\
$\mathrm{C}_{14: 0}$ & 6.9 & 2.8 & 4.4 & 0.3 & 10.2 \\
$\mathrm{C}_{16: 1} \omega 5$ & 0.6 & 0.8 & - & - & $\mathrm{ND}$ \\
$\mathrm{C}_{16: 1} \omega 7$ & 22.8 & 17.1 & 38.3 & 25.7 & 33.5 \\
$\mathrm{C}_{16: 1} \omega 9$ & 0.6 & 1.3 & 1.3 & - & $\mathrm{ND}$ \\
$\mathrm{C}_{16: 0}$ & 26.6 & 21.0 & 21.7 & 28.0 & 29.5 \\
$\mathrm{C}_{17: 1} \omega 8$ & 1.4 & 1.7 & 0.9 & - & $\mathrm{ND}$ \\
$\mathrm{C}_{18: 1} \omega 7$ & 2.9 & 2.7 & 5.4 & 28.6 & $\mathrm{ND}$ \\
$\mathrm{C}_{18: 1} \omega 6$ and/or $\omega 9$ & $18.8^{*}$ & $27.4^{*}$ & $9.0^{*}$ & - & 10.9 \\
$\mathrm{C}_{18: 0}$ & 2.9 & 4.6 & 0.8 & 1.1 & 7.7 \\
$\mathrm{Unidentified}_{\text {Summed features } \dagger}$ & 1.0 & 1.0 & 2.1 & 1.7 & 3.6 \\
$\quad 2$ & & & & & \\
2 & 0.2 & 0.3 & - & - & $\mathrm{ND}$ \\
7 & - & - & - & 1.7 & $\mathrm{ND}$ \\
7 & - & - & - & 0.9 & $\mathrm{ND}$ \\
\hline
\end{tabular}

${ }^{\star}$ Identified as $\mathrm{C}_{18: 1} \omega 9$.

$\dagger$ Summed features represent groups of two or three fatty acids that cannot be separated by the Microbial Identification System. Summed feature 2 consisted of $\mathrm{C}_{12: 0}$ aldehyde and/or an unidentified fatty acid with equivalent chain-length 10.928 , summed feature 3 consisted of $\mathrm{C}_{16: 1} \omega 7$ and/or iso- $\mathrm{C}_{15: 0} 2-\mathrm{OH}$ and summed feature 7 consisted of one or more of an unidentified fatty acid with equivalent chain-length 18.846, $\mathrm{C}_{19: 1} \omega 6$ and $\mathrm{C}_{19: 0}$ cyclo $\omega 10$.

stationary phase (5-7 days for the novel isolates, 2-3 days for Oceanobacter kriegii NBRC $15467^{\mathrm{T}}$ and 4 days for T. oleivorans DSM $14913^{\mathrm{T}}$ ) and were analysed as described previously (Fukunaga et al., 2008). The isoprenoid quinones of the isolates were Q-9 (97-99\%) and Q-8 (1$3 \%)$ and the isoprenoid quinones of Oceanobacter kriegii NBRC $15467^{\mathrm{T}}$ were Q-8 (91\%), Q-7 (7\%) and Q-9 (2\%), which confirmed the report by Satomi et al. (2002). The isoprenoid quinones of T. oleivorans DSM $14913^{\mathrm{T}}$ were Q$9(97 \%)$ and Q-8 (3\%). The major quinone in the novel isolates, Q-9, was clearly different from the major quinone in their closest phylogenetic neighbour with a validly published name, Oceanobacter kriegii NBRC $15467^{\mathrm{T}}$, Q-8.

For polar lipid analysis, cells were grown in dMBPyr broth with shaking ( 125 r.p.m.) at $28{ }^{\circ} \mathrm{C}$ to stationary phase (10 days for strain $2 \mathrm{O}^{\mathrm{T}}$ and 3 days for Oceanobacter kriegii
NBRC $15467^{\mathrm{T}}$ ). Polar lipids were extracted from 200$250 \mathrm{mg}$ freeze-dried cells (Minnikin et al., 1979) and separated by two-dimensional TLC on Kieselgel $60 \mathrm{~F}_{254}$ plates (Merck) using chloroform/methanol/water $(65: 25: 4$, by vol.) in the first dimension and chloroform/acetic acid/ methanol/water $(80: 18: 12: 5$, by vol.) in the second dimension. Total lipid content was revealed by spraying with $10 \%(\mathrm{w} / \mathrm{v})$ molybdophosphoric acid in ethanol and incubating at $140{ }^{\circ} \mathrm{C}$ for $1 \mathrm{~h}$. Specific functional groups were revealed by spraying with ninhydrin (Wako) (free amino groups), Dittmer and Lester reagent (Dittmer \& Lester, 1964) (phosphate groups), anisaldehyde/sulfuric acid/ethanol (1:1:18, by vol.) (glycolipids) and periodic acid-Schiff stain (Shaw, 1968) (vicinal hydroxyl groups). The polar lipid profiles are shown in Supplementary Fig. S2. Strain $2 \mathrm{O} 1^{\mathrm{T}}$ and Oceanobacter kriegii NBRC $15467^{\mathrm{T}}$ contained phosphatidylglycerol, a ninhydrin-positive phospholipid(s) and a few glycolipids. T. oleivorans DSM $14913^{\mathrm{T}}$ has also been shown to contain phosphatidylglycerol, phosphatidylethylamine (a ninhydrin-positive phospholipid) and glycolipids (Yakimov et al., 2004). Thus, no differences were detected in the polar lipid compositions of strain $2 \mathrm{O}^{\mathrm{T}}$, Oceanobacter kriegii NBRC $15467^{\mathrm{T}}$ and T. oleivorans DSM $14913^{\mathrm{T}}$ by the method used in this study.

To determine $\mathrm{G}+\mathrm{C}$ content, genomic DNA was extracted according to the protocol of Marmur (1961) from cells grown to early stationary phase in dMBPyr broth at $25{ }^{\circ} \mathrm{C}$ and analysed using HPLC (Mesbah et al., 1989). The DNA $\mathrm{G}+\mathrm{C}$ content of the isolates was $53.0-53.1 \mathrm{~mol} \%$, which was similar to the $\mathrm{G}+\mathrm{C}$ contents of Oceanobacter kriegii NBRC $15467^{\mathrm{T}}$ (54-56 mol\%; Bowditch et al., 1984) and T. oleivorans MIL-1 ${ }^{\mathrm{T}}$ (53.2 mol\%; Yakimov et al., 2004).

Quantitative DNA-DNA hybridization, using genomic DNA extracted as described above, was performed using the fluorometric hybridization method described by Ezaki et al. (1989), using $25 \%$ formamide at $56.8{ }^{\circ} \mathrm{C}$ for the hybridization reactions. DNA-DNA relatedness between each of the isolates was $\geqslant 75 \%$, which indicated that the isolates are representatives of the same species. The isolates showed $\leqslant 29 \%$ DNA-DNA relatedness with Oceanobacter kriegii NBRC $15467^{\mathrm{T}}$ (Supplementary Table S1).

Almost-complete 16S rRNA gene sequences of strains $2 \mathrm{O} 1^{\mathrm{T}}, 1 \mathrm{O} 14$ and $1 \mathrm{O} 18$ (Teramoto et al., 2009) showed 99.8-99.9\% sequence similarity. The 16S rRNA gene sequences were aligned with related sequences of members of the Gammaproteobacteria available in public databases using Clustal X (Thompson et al., 1997). Phylogenetic trees were inferred from the aligned sequences (1335 bp) using neighbour-joining (Saitou \& Nei, 1987) and maximum-likelihood (Swofford, 2000) algorithms and analysed using bootstrapping (Felsenstein, 1985) based on 1000 resamplings. The neighbour-joining tree is shown in Fig. 1. The isolates formed a coherent and distinct cluster that was supported by a high bootstrap value $(100 \%)$ within a stable phyletic group that contained Oceanobacter kriegii IFO $15467^{\mathrm{T}}$ and T. oleivorans MIL-1 ${ }^{\mathrm{T}}$. 16S rRNA 


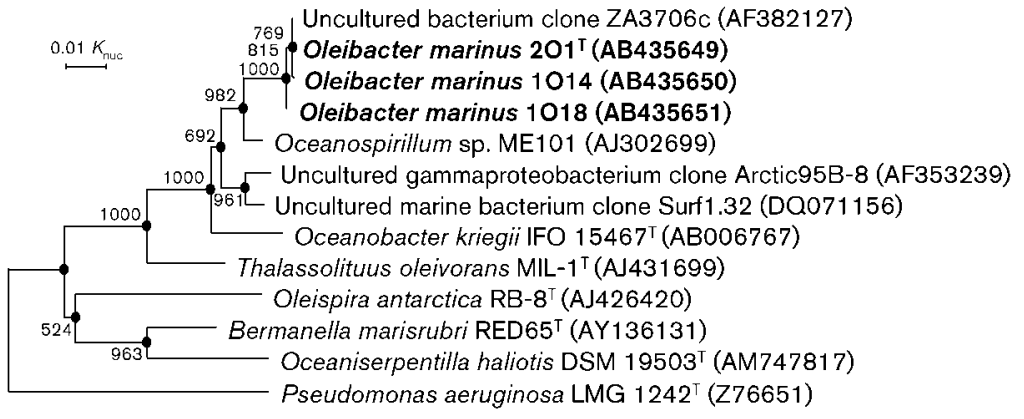

Fig. 1. Neighbour-joining tree based on $16 \mathrm{~S}$ rRNA gene sequence showing the phylogenetic positions of strains $2 \mathrm{O} 1^{\top}, 1014$ and 1018 and related taxa. Bootstrap values (>500) based on 1000 resamplings are shown at branch nodes. Filled circles indicate that the corresponding nodes were recovered in a tree generated with the maximum-likelihood method with bootstrap values $>60 \%$. Bar, 0.01 substitutions per nucleotide position.

gene sequence similarity between the isolates and Oceanobacter kriegii IFO $15467^{\mathrm{T}}$ was $96.4-96.5 \%$.

In summary, despite having high 16S rRNA gene sequence similarity, the isolates were different from Oceanobacter kriegii NBRC $15467^{\mathrm{T}}$ by having a different spectrum of substrates for growth and other phenotypic dissimilarities, especially the traits listed in Table 2, a different major quinone and $\mathrm{C}_{18: 1} \omega 9$ as a major fatty acid. The isolates were different from $T$. oleivorans DSM $14913^{\mathrm{T}}$ in their hydroxy fatty acid composition. In addition, the isolates showed high n-alkane-degrading activity (Supplementary Fig. S3); Oceanobacter kriegii NBRC $15467^{\mathrm{T}}$ did not degrade alkanes (Teramoto et al., 2009) and T. oleivorans DSM $14913^{\mathrm{T}}$ degraded alkanes significantly more slowly than the isolates when tested with the method described by Teramoto et al. (2009) (Teramoto \& Harayama, 2011). Also, a gene similar to alkB (alkane mono-oxygenase) is present in the isolates and absent from Oceanobacter kriegii NBRC $15467^{\mathrm{T}}$ (Bowditch et al., 1984; Teramoto et al., 2009; Yakimov et al., 2004).

On the basis of phenotypic, genotypic and chemotaxonomic data, it is proposed that strains $2 \mathrm{O} 1^{\mathrm{T}}, 1 \mathrm{O} 14$ and $1 \mathrm{O} 18$ are representatives of a novel genus and species, for which the name Oleibacter marinus gen. nov., sp. nov. is proposed.

\section{Description of Oleibacter gen. nov.}

Oleibacter [O.le'i.bac'ter. L. n. oleum oil; N.L. masc. n. bacter rod; N.L. masc. n. Oleibacter an oil (-degrading) rod].

According to $16 \mathrm{~S}$ rRNA gene sequence analysis, belongs to the Gammaproteobacteria. Cells are Gram-negative, motile, aerobic rods. n-Alkane-degrading activity is observed. Predominant cellular fatty acids are $\mathrm{C}_{16: 0}, \mathrm{C}_{16: 1} \omega 7$ and $\mathrm{C}_{18: 1} \omega 9$ and hydroxy fatty acids are $\mathrm{C}_{12: 0} 3-\mathrm{OH}$ and $\mathrm{C}_{10: 0}$ 3-OH. The major isoprenoid quinone is Q-9 and minor amounts of Q-8 are present. Polar lipids are phosphatidylglycerol, a ninhydrin-positive phospholipid(s) and glycolipids. The DNA G $+\mathrm{C}$ content of known strains of the type species is $53.0-53.1 \mathrm{~mol} \%$. The type species is Oleibacter marinus.

\section{Description of Oleibacter marinus sp. nov.}

Oleibacter marinus (ma.ri'nus. L. masc. adj. marinus of the sea, marine).

Table 2. Selected physiological and biochemical characteristics that differentiate strains of Oleibacter marinus gen. nov., sp. nov. from their closest culturable phylogenetic neighbours

Strains: 1 , Oleibacter marinus gen. nov., sp. nov. ( $n=3) ; 2$, Oceanobacter kriegii NBRC $15467^{\mathrm{T}} ; 3$, Thalassolituus oleivorans DSM $14913^{\mathrm{T}}$. Data were obtained in this study unless indicated. +, Positive; -, negative; ND, no data available.

\begin{tabular}{|c|c|c|c|}
\hline Characteristic & 1 & 2 & 3 \\
\hline Monopolar flagella & 1 & $1^{a_{\star}}$ & $1-4^{b}$ \\
\hline Growth at $4{ }^{\circ} \mathrm{C}$ & - & $-{ }^{a}$ & $+{ }^{b}$ \\
\hline Optimum temperature $\left({ }^{\circ} \mathrm{C}\right)$ & $25-30$ & $25-30$ & $20-25^{b}$ \\
\hline $\mathrm{pH}$ range & $6-10$ & $5-9$ & $7.5-9^{b}$ \\
\hline Reduction of nitrate & + & $+\left[-{ }^{a}\right]$ & $-{ }^{b}$ \\
\hline \multicolumn{4}{|l|}{ Fatty acids $(\%)$} \\
\hline $\mathrm{C}_{18: 1} \omega 6$ and/or $\omega 9$ & $9.0-27.4 \dagger$ & 0 & $10.9^{b}$ \\
\hline $\mathrm{C}_{18: 1} \omega 7$ & $2.7-5.4$ & 28.6 & $\mathrm{ND}$ \\
\hline Major 3-OH fatty acid (\% of total 3-OH) & $C_{12: 0}(58-67)$ & $\mathrm{C}_{10: 0}(51)\left[\mathrm{C}_{12: 0}(54)^{b}\right]$ & $\mathrm{C}_{12: 0}(100)^{b}$ \\
\hline Major isoprenoid quinone $(\%)$ & Q-9 (97-99) & Q-8 $(91)$ & Q-9 (97) \\
\hline
\end{tabular}

${ }^{\star}$ Data obtained from: $a$, Bowditch et al. (1984); b, Yakimov et al. (2004).

$\dagger \mathrm{C}_{18: 1} \omega 9$. 
Displays the following properties in addition to those given in the genus description. Cells are $0.3-0.6 \times 1.5-2.8 \mu \mathrm{m}$ and monoflagellated. Growth occurs at $10-40{ }^{\circ} \mathrm{C}$ (optimum $25-30{ }^{\circ} \mathrm{C}$ ), at $\mathrm{pH}$ 6-10 (optimum from $\mathrm{pH}$ 67 to $\mathrm{pH} 9)$ and with $1-7 \%(\mathrm{w} / \mathrm{v}) \mathrm{NaCl}$. Catalase- and oxidase-positive. As single carbon and energy sources, acetate, propionate and pyruvate are utilized, but Larabinose, D-fructose, D-glucose, ribose, glycolate, citrate, formate, DL-lactate, aspartate, L-asparagine and L-proline are not. With GN2 MicroPlates, $\beta$-hydroxybutyric acid, $\gamma$-hydroxybutyric acid, L-glutamic acid and Tween 80 are oxidized and Tween 40 is often oxidized. Exhibits high n-alkane-degrading activity. With API $20 \mathrm{NE}$, positive for urease, gelatinase and reduction of nitrate to nitrite. With API ZYM, positive for alkaline phosphatase, esterase (C4), esterase lipase (C8), lipase (C14), cystine arylamidase, leucine arylamidase, valine arylamidase, acid phosphatase and naphthol-AS-BI-phosphohydrolase, but negative for trypsin, $\alpha$-chymotrypsin, $\alpha$-galactosidase, $\beta$-galactosidase, $\beta$-glucuronidase, $\alpha$-glucosidase, $\beta$-glucosidase, $N$-acetyl- $\beta$ glucosaminidase, $\alpha$-fucosidase and $\alpha$-mannosidase.

The type strain is $2 \mathrm{O}^{\mathrm{T}}\left(=\mathrm{NBRC} 105760^{\mathrm{T}}=\mathrm{BTCC} \mathrm{B}\right.$ $675^{\mathrm{T}}$ ), isolated from seawater at Pari Island, located off Jakarta, Indonesia. Strains 1 O14 $(=$ NBRC $105758=$ BTCC B-676) and $1 \mathrm{O} 18$ (=NBRC $105759=$ BTCC B-677) were isolated from the same source and belong to the species.

\section{Acknowledgements}

We thank Tomohiko Tamura for advice on the polar lipid analysis and Chiaki Noritake and Ayako Koide for their technical assistance. We also thank Jean Euzéby for help with etymology. This work was conducted under a Joint Research Project between the Department of Biotechnology, National Institute of Technology and Evaluation, Japan, and the Indonesian Institute of Sciences (LIPI) and was supported by the New Energy and Industrial Technology Development Organization (grant no. P05032).

\section{References}

Bowditch, R. D., Baumann, L. \& Baumann, P. (1984). Description of Oceanospirillum kriegii sp. nov. and O. jannaschii sp. nov. and assignment of two species of Alteromonas to this genus as O. commune comb. nov. and O. vagum comb. nov. Curr Microbiol 10, 221-230.

Buck, J. D. (1982). Nonstaining ( $\mathrm{KOH})$ method for determination of Gram reactions of marine bacteria. Appl Environ Microbiol 44, 992993.

Cappello, S., Caruso, G., Zampino, D., Monticelli, L. S., Maimone, G., Denaro, R., Tripodo, B., Troussellier, M., Yakimov, M. \& Giuliano, L. (2007). Microbial community dynamics during assays of harbour oil spill bioremediation: a microscale simulation study. J Appl Microbiol 102, 184-194.

Coulon, F., McKew, B. A., Osborn, A. M., McGenity, T. J. \& Timmis, K. N. (2007). Effects of temperature and biostimulation on oildegrading microbial communities in temperate estuarine waters. Environ Microbiol 9, 177-186.

Dittmer, J. C. \& Lester, R. L. (1964). A simple, specific spray for the detection of phospholipids on thin-layer chromatograms. J Lipid Res $15,126-127$.
Dyksterhouse, S. E., Gray, J. P., Herwig, R. P., Lara, J. C. \& Staley, J. T. (1995). Cycloclasticus pugetii gen. nov., sp. nov., an aromatic hydrocarbon-degrading bacterium from marine sediments. Int $J$ Syst Bacteriol 45, 116-123.

Ezaki, T., Hashimoto, Y. \& Yabuuchi, E. (1989). Fluorometric deoxyribonucleic acid-deoxyribonucleic acid hybridization in microdilution wells as an alternative to membrane filter hybridization in which radioisotopes are used to determine genetic relatedness among bacterial strains. Int J Syst Bacteriol 39, 224-229.

Felsenstein, J. (1985). Confidence limits on phylogenies: an approach using the bootstrap. Evolution 39, 783-791.

Fukunaga, Y., Kurahashi, M., Yanagi, K., Yokota, A. \& Harayama, S. (2008). Acanthopleuribacter pedis gen. nov., sp. nov., a marine bacterium isolated from a chiton, and description of Acanthopleuribacteraceae fam. nov., Acanthopleuribacterales ord. nov., Holophagaceae fam. nov., Holophagales ord. nov. and Holophagae classis nov. in the phylum 'Acidobacteria'. Int J Syst Evol Microbiol 58, 2597-2601.

Gerhardt, P., Murray, R. G. E., Wood, W. A. \& Krieg, N. R. (1994). Methods for General and Molecular Bacteriology. Washington, DC: American Society for Microbiology.

Hara, A., Syutsubo, K. \& Harayama, S. (2003). Alcanivorax which prevails in oil-contaminated seawater exhibits broad substrate specificity for alkane degradation. Environ Microbiol 5, 746-753.

Harayama, S., Kasai, Y. \& Hara, A. (2004). Microbial communities in oil-contaminated seawater. Curr Opin Biotechnol 15, 205-214.

Head, I. M., Jones, D. M. \& Roling, W. F. (2006). Marine microorganisms make a meal of oil. Nat Rev Microbiol 4, 173-182.

Kasai, Y., Kishira, H., Syutsubo, K. \& Harayama, S. (2001). Molecular detection of marine bacterial populations on beaches contaminated by the Nakhodka tanker oil-spill accident. Environ Microbiol 3, 246255.

Kasai, Y., Kishira, H. \& Harayama, S. (2002). Bacteria belonging to the genus Cycloclasticus play a primary role in the degradation of aromatic hydrocarbons released in a marine environment. Appl Environ Microbiol 68, 5625-5633.

Marmur, J. (1961). A procedure for the isolation of deoxyribonucleic acid from microorganisms. J Mol Biol 3, 208-218.

Maruyama, A., Ishiwata, H., Kitamura, K., Sunamura, M., Fujita, T., Matsuo, M. \& Higashihara, T. (2003). Dynamics of microbial populations and strong selection for Cycloclasticus pugetii following the Nakhodka oil spill. Microb Ecol 46, 442-453.

McKew, B. A., Coulon, F., Osborn, A. M., Timmis, K. N. \& McGenity, T. J. (2007). Determining the identity and roles of oil-metabolizing marine bacteria from the Thames estuary, UK. Environ Microbiol 9, $165-176$.

Mesbah, M., Premachandran, U. \& Whitman, W. B. (1989). Precise measurement of the $\mathrm{G}+\mathrm{C}$ content of deoxyribonucleic acid by highperformance liquid chromatography. Int J Syst Bacteriol 39, 159-167.

Minnikin, D. E., Collins, M. D. \& Goodfellow, M. (1979). Fatty acid and polar lipid composition in the classification of Cellulomonas, Oerskovia and related taxa. J Appl Bacteriol 47, 87-95.

Prince, R. C. (2005). The microbiology of marine oil spill bioremediation. In Petroleum Microbiology, pp. 317-335. Edited by B. Ollivier \& M. Magot. Washington, DC: American Society for Microbiology.

Roling, W. F., Milner, M. G., Jones, D. M., Lee, K., Daniel, F., Swannell, R. J. \& Head, I. M. (2002). Robust hydrocarbon degradation and dynamics of bacterial communities during nutrient-enhanced oil spill bioremediation. Appl Environ Microbiol 68, 5537-5548.

Roling, W. F., Milner, M. G., Jones, D. M., Fratepietro, F., Swannell, R. P., Daniel, F. \& Head, I. M. (2004). Bacterial community dynamics 
and hydrocarbon degradation during a field-scale evaluation of bioremediation on a mudflat beach contaminated with buried oil. Appl Environ Microbiol 70, 2603-2613.

Saitou, N. \& Nei, M. (1987). The neighbor-joining method: a new method for reconstructing phylogenetic trees. Mol Biol Evol 4, 406425.

Satomi, M., Kimura, B., Hamada, T., Harayama, S. \& Fujii, T. (2002). Phylogenetic study of the genus Oceanospirillum based on 16S rRNA and gyrB genes: emended description of the genus Oceanospirillum, description of Pseudospirillum gen. nov., Oceanobacter gen. nov. and Terasakiella gen. nov. and transfer of Oceanospirillum jannaschii and Pseudomonas stanieri to Marinobacterium as Marinobacterium jannaschii comb. nov. and Marinobacterium stanieri comb. nov. Int J Syst Evol Microbiol 52, 739-747.

Shaw, N. (1968). The detection of lipids on thin-layer chromatograms with the periodate-Schiff reagents. Biochim Biophys Acta 164, 435436.

Swofford, D. (2000). PAUP 4.0b7a: phylogenetic analysis using parsimony (and other methods). Sunderland, MA: Sinauer Associates.

Teramoto, M. \& Harayama, S. (2011). Potential for petroleum aliphatic hydrocarbon degradation of the key bacteria in temperate seas. In The Marine Environment: Ecology, Management and Conservation. Edited by A. D. Nemeth. New York: Nova Science (in press).
Teramoto, M., Suzuki, M., Okazaki, F., Hatmanti, A. \& Harayama, S. (2009). Oceanobacter-related bacteria are important for the degradation of petroleum aliphatic hydrocarbons in the tropical marine environment. Microbiology 155, 3362-3370.

Thompson, J. D., Gibson, T. J., Plewniak, F., Jeanmougin, F. \& Higgins, D. G. (1997). The CLUSTAL_X windows interface: flexible strategies for multiple sequence alignment aided by quality analysis tools. Nucleic Acids Res 25, 4876-4882.

Yakimov, M. M., Golyshin, P. N., Lang, S., Moore, E. R., Abraham, W. R., Lunsdorf, H. \& Timmis, K. N. (1998). Alcanivorax borkumensis gen. nov., sp. nov., a new, hydrocarbon-degrading and surfactantproducing marine bacterium. Int J Syst Bacteriol 48, 339-348.

Yakimov, M. M., Giuliano, L., Denaro, R., Crisafi, E., Chernikova, T. N., Abraham, W.-R., Luensdorf, H., Timmis, K. N. \& Golyshin, P. N. (2004). Thalassolituus oleivorans gen. nov., sp. nov., a novel marine bacterium that obligately utilizes hydrocarbons. Int J Syst Evol Microbiol 54, 141-148.

Yakimov, M. M., Denaro, R., Genovese, M., Cappello, S., D’Auria, G., Chernikova, T. N., Timmis, K. N., Golyshin, P. N. \& Giluliano, L. (2005). Natural microbial diversity in superficial sediments of Milazzo Harbor (Sicily) and community successions during microcosm enrichment with various hydrocarbons. Environ Microbiol 7, $1426-1441$. 